\title{
Study the Corrosion and Corrosion Protection of Brass Sculpture by Atmospheric Pollutants in Winter Season
}

\author{
Rajesh Kumar Singh* and Noor Alam \\ Department of Chemistry, J P University, India
}

*Corresponding author: Rajesh Kumar Singh, Department of Chemistry, J P University, India

\begin{abstract}
Brass is an important metalloid which is used in construction of sculptures. It is noticed that sculpture of brass is corroding due to interaction of pollutants. The pollutants develop chemical and electrochemical reaction on the surface of base material. Their concentrations of corrosive pollutants are increased in winter season. The air quality becomes very poor in winter season. Inside sculpture different forms of corrosion are observed like galvanic, pitting, stress, crevice etc. The major components of pollutants are oxides of carbon, oxides of nitrogen, oxides of sulphur, ammonia, ozone and particulates. Among these pollutants oxides of sulphur and ammonia are major corroder of brass. Ammonia is observed moist air to form ammonium hydroxide. It produces chemical reaction with brass metal and form complex compounds like $\left[\mathrm{Zn}\left(\mathrm{NH}_{4}\right)_{4}\right](\mathrm{OH})_{2},\left[\mathrm{Zn}\left(\mathrm{NH}_{4}\right)_{4}\right] \mathrm{SO}_{4},\left[\mathrm{Zn}\left(\mathrm{NH}_{4}\right)\right] \mathrm{CO}_{3},\left[\mathrm{Cu}\left(\mathrm{NH}_{4}\right)_{4}\right](\mathrm{OH})_{2}$, $\left[\mathrm{Cu}\left(\mathrm{NH}_{4}\right)_{4}\right] \mathrm{SO}_{4},\left[\mathrm{Cu}\left(\mathrm{NH}_{4}\right)\right] \mathrm{CO}_{3}$ etc. Oxides of sulphur react with moist air to exhibit sulphurous and sulphuric acids. They interact with brass to develop corrosion cell zinc metal and it is oxidized into $\mathrm{Zn}^{2+}$ ions and these ions are active to humidity and carbon dioxide to yield $\mathrm{Zn}(\mathrm{OH})_{2} \cdot \mathrm{ZnCO}_{3} \cdot 2 \mathrm{H}_{2} \mathrm{O}$. Copper is converted into $\mathrm{Cu}^{2+}$ and it reacts with moist air and carbon dioxide to produce $\mathrm{Cu}(\mathrm{OH})_{2} \cdot \mathrm{Cu}\left(\mathrm{CO}_{3}\right)_{2}$ and these complex compound detached on the surface of brass metal by rain water. These pollutants change their physical, chemical and mechanical properties and they also tarnish their facial appearance. Brass' sculpture is affected by uniform corrosion. This type of corrosion can be control by nanocoating and electrospray techniques. For this work (6Z)-5,8-dihydrazono5,8-dibenzo[a,c][8]annulene and TiO2 are used as nanocoating and electrospray materials. The corrosion rate of material was determined by gravimetric and potentiostat technique. The nanocoating and electrospray compounds are formed a composite layer on surface of base metal. The formation of composite layer is analyzed by thermal parameters like activation energy, heat of adsorption, free energy, enthalpy and entropy. These thermal parameters were calculated by Arrhenius, Langmuir isotherm and transition state equations. Thermal parameters results are depicted that both materials are adhered with sculpture through chemical bonding. The surface coverage area and coating efficiency indicates that nanocoating and electrospray are produced a protective barrier in ammonia and sulphur dioxide atmosphere.
\end{abstract}

Keywords: Brass sculpture; Corrosion; Atmospheric pollutants; Nanocoating; Electrospray; Sulphur dioxide; Composite barrier

\section{Introduction}

The sculpture of brass comes in contact of contaminated air thus its deterioration starts for protection various types methods can be applied [1]. Brass [2] has major components is copper and zinc. $\mathrm{Zn}$ reacts the hot air to produce $\mathrm{ZnO}$ which is active in humidity [3] to convert into $\mathrm{Zn}(\mathrm{OH})_{2}$. In moist air [4], they form $\mathrm{CuO}, \mathrm{ZnO}$, $\mathrm{Cu}(\mathrm{OH})_{2}$ and $\mathrm{Zn}(\mathrm{OH})_{2}$. Both metals are active with sulphur to yield $\mathrm{Cu} 2 \mathrm{~S}, \mathrm{CuS}$ and $\mathrm{ZnS}$ and these metallic sulphides [5] react with moist air to give $\mathrm{Cu}(\mathrm{OH})_{2}, \mathrm{Zn}(\mathrm{OH})_{2}, \mathrm{CuSO}_{4}$ and $\mathrm{ZnSO}_{4}$. The hydroxides of these metals interact with $\mathrm{CO}_{2}$ to produce $\mathrm{CuCO}_{3}$ and $\mathrm{ZnCO}_{3}$. Sulphur dioxide [6] is a culprit of brass. It undergoes with $\mathrm{Cu}(\mathrm{OH})_{2}$ and $\mathrm{Zn}(\mathrm{OH})_{2}$ to convert into $\mathrm{CuSO}_{4}$ and $\mathrm{ZnSO}_{4}$. Moist $\mathrm{SO}_{2}$ yields $\mathrm{H}_{2} \mathrm{SO}_{3}$ and $\mathrm{H}_{2} \mathrm{SO}_{4}$ whereas they create acidic environment [7] for brass and generate corrosion cell on their surface. It accelerates disintegration [8] in metal components of sculpture of brass. Brass is highly sensitive to ambient of ammonia gas [9]. It interacts with humid atmosphere [10] to $\mathrm{NH} 4 \mathrm{OH}$ and it deposits on the surface brass metal [11] thus it converts into a complex layer of $\left[\mathrm{Cu}\left(\mathrm{NH}_{3}\right)_{4}\right]$ $(\mathrm{OH})_{2}$ and $\left[\mathrm{Zn}\left(\mathrm{NH}_{3}\right)_{4}\right](\mathrm{OH})_{2}$ that layer erosion starts in rain water. $\left[\mathrm{Cu}\left(\mathrm{NH}_{3}\right)_{4}\right](\mathrm{OH})_{2}$ and $\left[\mathrm{Zn}\left(\mathrm{NH}_{3}\right)_{4}\right](\mathrm{OH})_{2}$ complex compounds [12] come in contact of $\mathrm{H} 2 \mathrm{SO} 4$ environment to produce $\left[\mathrm{Cu}\left(\mathrm{NH}_{3}\right)_{4}\right] \mathrm{SO}_{4}$ 
and $\left[\mathrm{Zn}\left(\mathrm{NH}_{3}\right)_{4}\right] \mathrm{SO}_{4}$ that complex layer is eroded in rain water. In acidic medium brass outer face has developed $\mathrm{CuSO}_{4}$ and $\mathrm{ZnSO}_{4}$ when dust particulates [13] are deposited on their surface which contains $\mathrm{Fe}$ to remove $\mathrm{Cu}$ and $\mathrm{Zn}$ from outer surface. Dust particulates are possessed oxides of alkali metal in presence of moisture, it produces $\mathrm{NaOH}$ or $\mathrm{KOH}$ [14] that is create hostile environment for $\mathrm{Zn}$ and it forms complex compound [15] $\mathrm{Na}_{2}\left[\mathrm{Zn}(\mathrm{OH})_{4}\right]$ or $\mathrm{Na}\left[\mathrm{Zn}(\mathrm{OH})_{3} \cdot \mathrm{H}_{2} \mathrm{O}\right]$ or $\mathrm{Na}\left[\mathrm{Zn}(\mathrm{OH})_{3^{\circ}}\left(\mathrm{H}_{2} \mathrm{O}\right)_{3}\right]$. The oxides of $\mathrm{NO}_{2}$ reacts with moist air to give $\mathrm{HNO}_{3}$ that acid produces chemical reaction with $\mathrm{Cu}$ and it converted into $\mathrm{Cu}\left(\mathrm{NO}_{3}\right)_{2}$. Some organic acids [16] available in air like acetic acid which develop corrosive environment for $\mathrm{Cu}$ and $\mathrm{Zn}$ which converts $\mathrm{Cu}$ into $\mathrm{Cu}_{2}\left(\mathrm{CH}_{3} \mathrm{COO}\right)_{4} \cdot \mathrm{H}_{2} \mathrm{O}$ and $\mathrm{Zn}$ into $\left(\mathrm{CH}_{3} \mathrm{COO}\right)_{6}$. $\mathrm{Zn}_{4} \mathrm{O}$ complex compounds [17]. They are eroded by rain water on the surface of brass. Organic compounds [18] like amnio and sulpur increased day by day in atmosphere. They develop hostile environment for brass and corroding it. Corrosive pollutants [19] concentrations like oxides of carbon, oxides of nitrogen, oxides of sulphur, hydride of sulphur and nitrogen, ozone and particulates are enhanced due to industrials wastes, effluents, flues and other factors are like burning of coals, woods and cow dung cakes. Harmful pollutants [20] come into atmosphere through agricultural wastes, human wastes, pharmaceutical wastes, household wastes, food wastes and decomposition of living things. Various types of transports like road, water and air are evolving $\mathrm{CO}, \mathrm{NO}_{2}$ and $\mathrm{SO}_{2}$ gases which produce acidic environments for brass. Several types of techniques are used to control the corrosion of brass like metallic coating; polymeric coating, paint coating, organic and inorganic coating of materials but these didn't give satisfactory results in corrosive medium. Some organic and inorganic inhibitors are applied to protect the corrosion of materials in acidic but they provide good results. Hot dipping, electroplating and galvanization techniques is used as protective tools for brass corrosion in acidic medium but these methods don't shave base metals. In this work it is to mitigate corrosion of brass corrosion by nanocoating and filler techniques. These materials form composite barrier on the surface base metal and blocked porosities and stop diffusion or osmosis process of pollutants.

\section{Experimental}

Brass coupons $15 \mathrm{sqcm}$ were taken for experimental analysis. Samples surface were rubbed with emery paper, rinsed with acetone, dry them and kept into desiccators. Sample kept 20 meter height of roof in open sky and it observed that colour of brass can be changed. Corrosion rate was determined in winter season by weight loss method. The concentration of $\mathrm{SO}_{2}$ in November 75ppm, December 90ppm, January 105ppm and February 120ppm and temperatures recorded in this period were 298K, 294K, $291 \mathrm{~K}$ and 295K. Synthesis organic compound (6Z)-5,8-dihydrazono5,8-dibenzo[a,c][8]annulene used as nanocoating and $\mathrm{TiO}_{2}$ as filler and corrosion of brass metal calculated in above mentioned concentrations and temperatures in winter season. Both compounds formed a composite barrier on surface of base metal (Figures 1-4). Surface adsorption phenomenon studied by thermal parameters like activation energy, heat of adsorption, free energy, enthalpy and entropy.Potentiostat/Galvanostat model EG\&G used for corrosion potential, corrosion current and corrosion current density. Brass sample put between $\mathrm{H} 2 \mid \mathrm{Pt}$ electrode as auxiliary electrode and $\mathrm{Hg}_{2} \mathrm{Cl}_{2} \mid \mathrm{HgCl}_{2}$ electrode reference electrode.
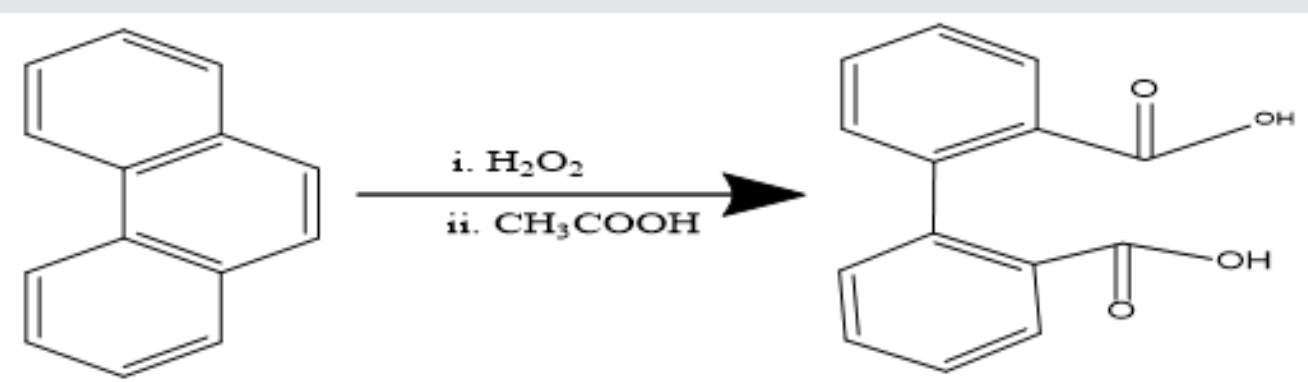

phenanthrene

[1,1'-bipheny1]-2,2'-dicarboxylic acid
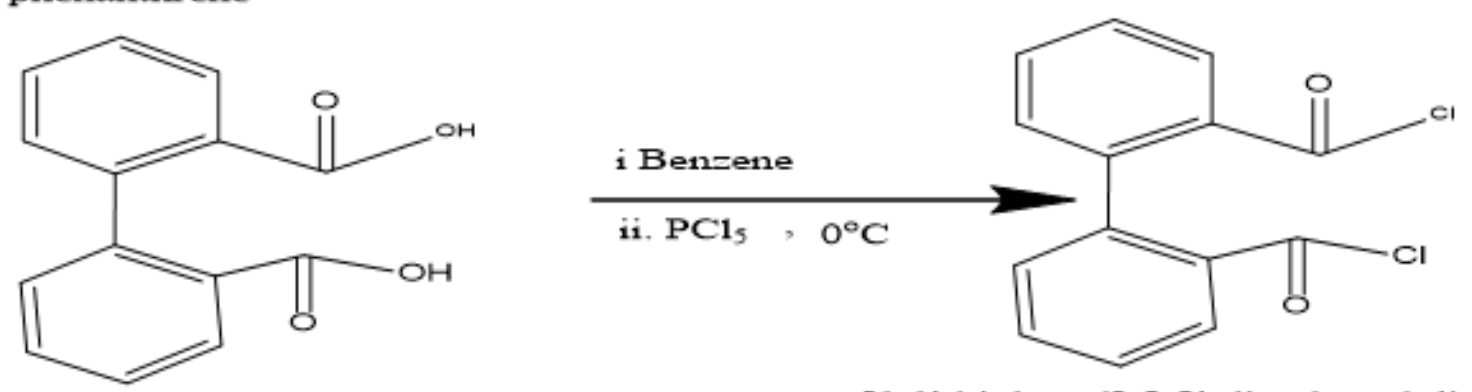

[1,1'-bipheny1]-2,2'-dicarboxylic acid

[1,1'-bipheny1]-2,2'-dicarbonyl dichloricle

Figure 1 
<smiles>O=C(Cl)c1ccccc1-c1ccccc1C(=O)Cl</smiles>

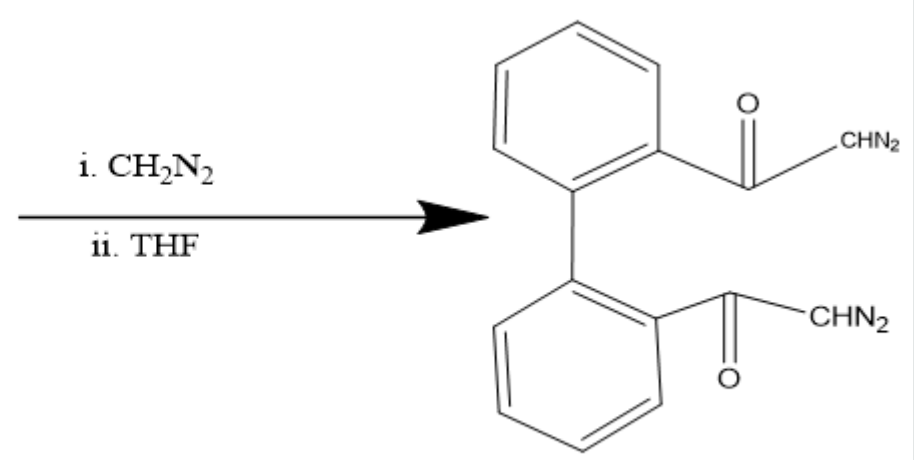

[1,1'-biphenyl]-2,2'-dicarbonyl dichloride

Figure 2<smiles>[NH]C(=O)c1ccccc1-c1ccccc1C(=O)C(N)N</smiles><smiles>C[C@H](C(=O)O)C(C)(C)Cl</smiles>

(Z)-dibenzo[a,c][8]annulene-5,8-dione

Figure 3<smiles>O=c1ccc(=O)c2ccccc2c2ccccc12</smiles>

(Z)-dibenzo[a,c][8]annulene-5,8-dione

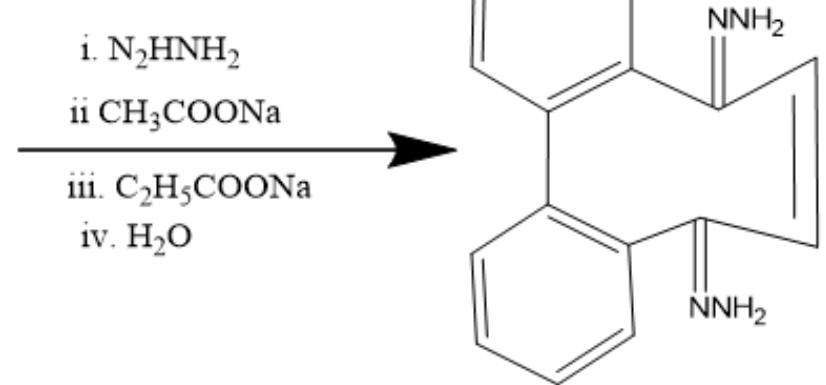

(6Z)-5,8-dihydrazono-5,8-dihydrodibenzo[ $a, c][8]$ annulene

Figure 4
Synthesis of (6Z)-5,8-dihydrazono-5,8-dibenzo[a,c][8] annulene

Phenatharene was oxidized into [1,1'-biphenyl]-2,2'dicarboxylic acid by the use of $\mathrm{H}_{2} \mathrm{O}_{2}$ in presence of $\mathrm{CH}_{3} \mathrm{COOH}$. When [1,1'-biphenyl]-2,2'-dicarboxylic acid was treated in $\mathrm{PCl}_{5}$ in benzene solution at $0 \quad{ }^{\circ} \mathrm{C}$ temperature, [1,1'-biphenyi]-2,2'-dicarbonyl chloride was obtained. It reacted with diazomethane to produce yield [1,1'-biphenyl]-2,2'-dicarboxodiazomethan which heated $\mathrm{Cu}(\mathrm{acac})_{2}$ in presence THF to yield (Z)-dibenzo[a,c][8]annulene5,8-dione. It was used with hydrazine hydrate in ethyl alcohol to give (6Z)-5,8-dihydrazone-5,8-dihydrodibenzo[a,c][8]annulene.

\section{Results and Discussion}

Brass metal was exposed in moist $\mathrm{SO}_{2}$ environment in $75 \mathrm{ppm}$, 90ppm, 105ppm and $120 \mathrm{ppm}$ concentrations and $298{ }^{\circ} \mathrm{K}, 294{ }^{\circ} \mathrm{K}$, 
$291{ }^{\circ} \mathrm{K}$ and $295{ }^{\circ} \mathrm{K}$ temperatures. The corrosion rate of brass metal was determined in winter season without coating and with coating (6Z)-5,8-dihydrazone-5,8-dihydrodibenzo[a,c][8]annulene and

Table 1: Corrosion of Brass Sculpture in Winter Season in $\mathrm{SO}_{2}$ medium.

\begin{tabular}{|c|c|c|c|c|c|c|}
\hline Month & Days & $\left.\mathbf{S O}_{\mathbf{2}} \mathbf{( P P M}\right)$ & $\mathbf{K}_{\mathbf{o}}(\mathbf{m m p y})$ & $\mathbf{l o g K}_{\mathbf{o}}$ & $\left.\mathbf{T e m p}^{\mathbf{0}} \mathbf{K}\right)$ & $\mathbf{( 1 0 0 0 X 1 / T ) K}^{\mathbf{1}}$ \\
\hline Nov & 30 & 75 & 3456 & 3.538 & 298 & 3.36 \\
\hline Dec & 31 & 90 & 4073 & 3.609 & 294 & 3.40 \\
\hline Jan & 31 & 105 & 4356 & 3.639 & 291 & 3.54 \\
\hline Feb & 28 & 120 & 4448 & 3.648 & 295 & 3.38 \\
\hline
\end{tabular}

Corrosion Control of Brass Sculpture by nanocoating of (6Z)-5,8-dihydrazone-5,8-dibenzo[a,c][8]annulene [NC] in $\mathrm{SO}_{2} \mathrm{Medium}$

\begin{tabular}{|c|c|c|c|c|c|c|c|c|}
\hline Month & Days & $\mathrm{SO}_{2}$ (PPM) & $\mathrm{C}(\mathrm{mM})$ & K(mmpy) & $\log K$ & $\log (\theta / 1-\theta)$ & Temp(K) & $(1000 X 1 / T) K^{-1}$ \\
\hline Nov & 30 & 75 & 25 & 1723 & 3.236 & -0.281 & 298 & 3.36 \\
\hline Dec & 31 & 90 & 30 & 1975 & 3.295 & -0.513 & 294 & 3.40 \\
\hline Jan & 31 & 105 & 40 & 2204 & 3.343 & -0.495 & 291 & 3.54 \\
\hline Feb & 28 & 120 & 45 & 2086 & 3.319 & -0.545 & 295 & 3.38 \\
\hline \multicolumn{9}{|c|}{ Corrosion Control of Brass Sculpture by Electrospray of $\mathrm{TiO}_{2}$ in $\mathrm{SO}_{2}$ Medium } \\
\hline Month & Days & $\mathrm{SO}_{2}(\mathrm{PPM})$ & $\mathrm{C}(\mathrm{mM})$ & K(mmpy) & $\log K$ & $\log (\theta / 1-\theta)$ & Temp(K) & $(1000 \mathrm{X} 1 / \mathrm{T}) \mathrm{K}^{-1}$ \\
\hline Nov & 30 & 75 & 5 & 1280 & 3.107 & 0.393 & 25 & 3.36 \\
\hline Dec & 31 & 90 & 10 & 1604 & 3.205 & 0.234 & 21 & 3.40 \\
\hline Jan & 31 & 105 & 15 & 1128 & 3.052 & 0.416 & 18 & 3.54 \\
\hline $\mathrm{Feb}$ & 28 & 120 & 20 & 1099 & 3.041 & 0.331 & 22 & 3.38 \\
\hline
\end{tabular}

Surface coverage area and \% Coating efficiency by Nanocoating material (6Z)-5,8-dihydrazono-5,8-dibenzo[a,c][8]annulene [NC] in $\mathrm{SO}_{2}$

\begin{tabular}{|c|c|c|c|c|c|c|c|c|}
\hline Month & Days & $\mathrm{SO}_{2}(\mathrm{PPM})$ & $\mathrm{C}(\mathrm{mM})$ & $\boldsymbol{\theta}$ & $\%$ CE & $\log (\theta / 1-\theta)$ & Temp(K) & $(1000 X 1 / \mathrm{T}) \mathrm{K}^{-1}$ \\
\hline Nov & 30 & 75 & 25 & 0.5014 & 50.14 & -0.281 & 298 & 3.36 \\
\hline Dec & 31 & 90 & 30 & 0.5150 & 51.50 & -0.513 & 294 & 3.40 \\
\hline Jan & 31 & 105 & 40 & 0.4940 & 49.40 & -0.495 & 291 & 3.54 \\
\hline Feb & 28 & 120 & 45 & 0.5310 & 53.10 & -0.545 & 295 & 3.38 \\
\hline \multicolumn{9}{|c|}{ Surface coverage area and \% Coating efficiency by Electrospray of $\mathrm{TiO}_{2}$ in $\mathrm{SO}_{2}$ Medium } \\
\hline Month & Days & $\mathrm{SO}_{2}$ (PPM) & $\mathrm{C}(\mathrm{mM})$ & $\theta$ & $\% \mathrm{CE}$ & $\log (\theta / 1-\theta)$ & Temp(K) & $(1000 X 1 / \mathrm{T}) \mathrm{K}^{-1}$ \\
\hline Nov & 30 & 75 & 5 & 0.6296 & 62.96 & 0.393 & 298 & 3.36 \\
\hline Dec & 31 & 90 & 10 & 0.6061 & 60.61 & 0.234 & 294 & 3.40 \\
\hline Jan & 31 & 105 & 15 & 0.7410 & 74.10 & 0.416 & 291 & 3.54 \\
\hline Feb & 28 & 120 & 20 & 0.7529 & 75.29 & 0.331 & 295 & 3.38 \\
\hline
\end{tabular}

The corrosion rate of brass metal was recorded in the months of November, December, January and February, the results (Table 1) was shown that corrosion rate of metal increased in January to February but theses values were reduced with coating and filler materials like (6Z)-5,8-dihydrazone-5,8-dihydrodibenzo[a,c][8] annulene and $\mathrm{TiO}_{2}$. It was clearly noticed in (Figure 5) $\mathrm{K}$ versus Month. Brass metal kept into 75ppm, 90ppm, 105ppm and 120ppm of $\mathrm{SO}_{2}$ medium in month of Nov, Dec, Jan and Feb without coating. It was coated with $25 \mathrm{mM}, 30 \mathrm{mM}, 40 \mathrm{mM}$ and $45 \mathrm{mM}$ concentrations of (6Z)-5,8-dihydrazone-5,8-dibenzo[a,c][8]annulene, and again kept into same concentrations of $\mathrm{SO}_{2}$. After coating of (6Z)-5, 8-dihydrazone-5,8-dibenzo[a,c][8]annulene electrospray coating of $\mathrm{TiO}_{2}$ used at $5 \mathrm{mM}, 10 \mathrm{mM}, 15 \mathrm{~mm}$ and $20 \mathrm{mM}$ concentrations and same concentrations $\mathrm{SO}_{2}$ Nov to Feb. The corrosion rates of in these three cases were written in (Table 1). These results were shown that corrosion rates without coating increased, it values decreased coating with (6Z)-5, 8-dihydrazone-5,8-dibenzo[a,c][8]annulene but their values more reduced with $\mathrm{TiO}_{2}$ electrospray. These trends were shown in (Figure 6) which plotted K versus C. The corrosion rates of brass metal at different temperatures $298{ }^{\circ} \mathrm{K}, 294{ }^{\circ} \mathrm{K}, 291$ ${ }^{0} \mathrm{~K}$ and $2950 \mathrm{~K}$ without and with coating were recorded in (Table 1). The addition of nanocoating and electrospray were reduced the corrosion rates as temperatures variation, it noticed in $\mathrm{K}$ versus $\mathrm{T}$ in (Figure 7). 


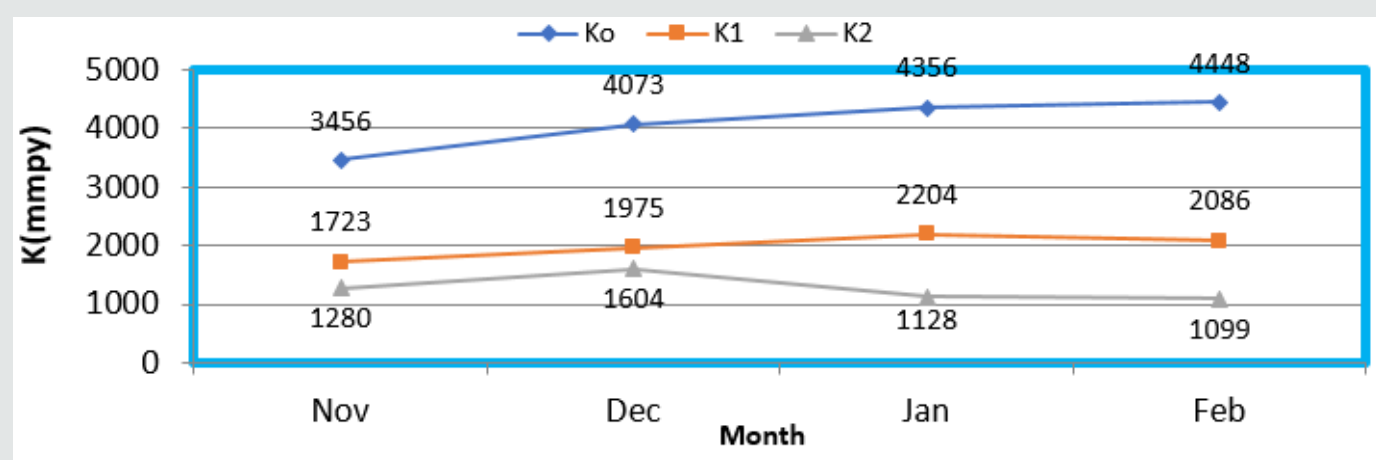

Figure 5: $\mathrm{K}(\mathrm{mmpy}) \mathrm{V}_{\mathrm{s}}$ Months for brass metals.

\begin{tabular}{|c|c|c|c|c|}
\hline \multicolumn{5}{|c|}{$\leadsto$ Series1 $\rightarrow-$ Series2 } \\
\hline \multirow{6}{*}{$\begin{array}{l}4000 \\
3000 \\
2000 \\
1000\end{array}$} & & 4073 & 4356 & 4448 \\
\hline & 3456 & $\rightarrow=$ & & \\
\hline & Noy & Dec & Jah & Feb \\
\hline & 1723 & 1975 & 2204 & 2088 \\
\hline & & 1604 & & \\
\hline & 1280 & & 1128 & 1099 \\
\hline & 298 & 294 & 291 & 295 \\
\hline
\end{tabular}

Figure 6: $\mathrm{KV}_{\mathrm{s}} \mathrm{T}$ nanocoating and electrospray.

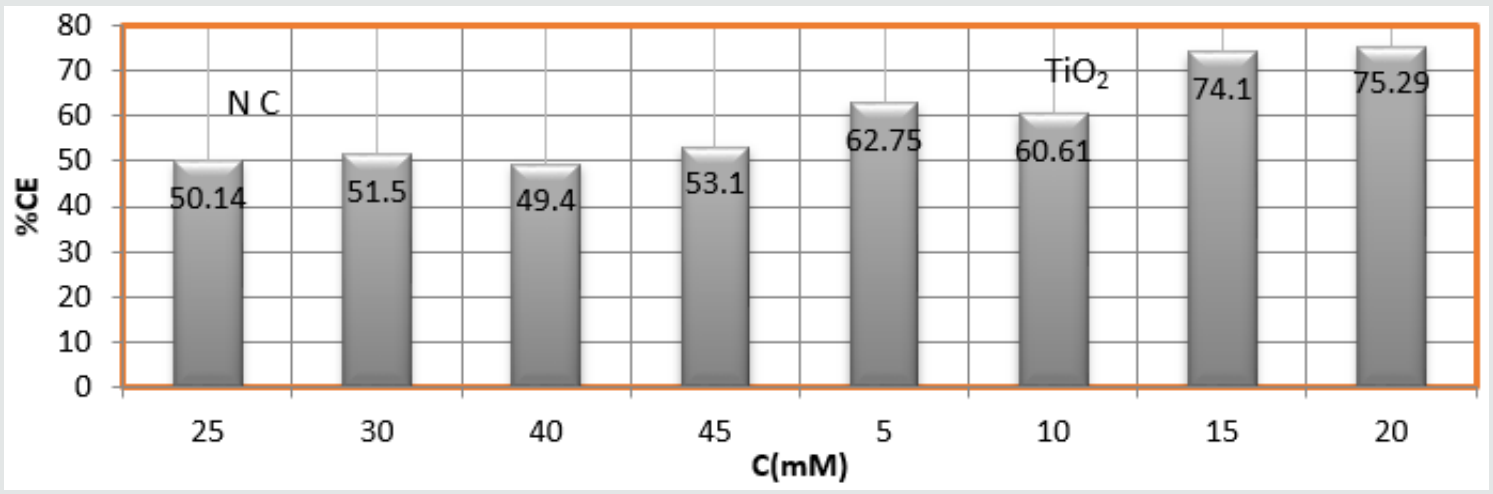

Figure 7: \% $\mathrm{CE} \mathrm{V}_{\mathrm{s}} \mathrm{C}(\mathrm{mM})$ nanocoating and electrospray.

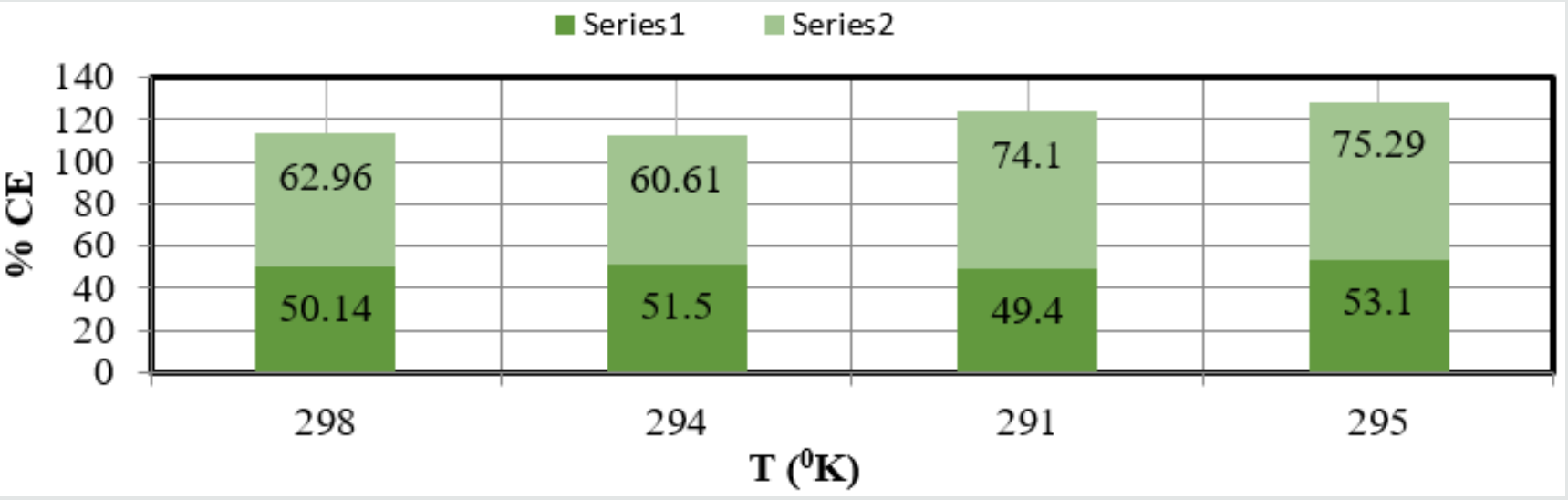

Figure 8: \% $\mathrm{CE} \mathrm{V}_{\mathrm{s}} \mathrm{T}$ for nanocoating and electrospray. 
(Figure 8) plot between \%C (percentage coating efficiency) versus $\mathrm{C}$ (concentrations in $\mathrm{mM}$ ) indicated that nanocoating compound (6Z)-5, 8-dihydrazone-5,8-dibenzo[a,c][8]annulene increased coating efficiency but $\mathrm{TiO}_{2}$ electrospray produced more coating efficiency with respect of nanocoating compound. The values of $\%$ coating efficiency were calculated by formula $\% \mathrm{CE}=$ (1-K/Ko) X100 (where Ko is corrosion rate without coating and $\mathrm{K}$ is corrosion rate with coating) and their values were given (Table 1). (Figure 9) show plot between \%C (percentage coating efficiency) versus $\mathrm{T}$ (temperature in $\mathrm{K}$ ). This figure indicated that percentage coating efficiency enhanced as temperatures varies in Nov to Feb months and their values were recorded in (Table 1). Figure 6 plotted between $\theta$ (surface coverage area) versus $C$ (concentration in $\mathrm{mM}$ ) and covered areas were produced by (6Z)-5, 8-dihydrazone5,8-dibenzo[a,c][8]annulene and $\mathrm{TiO}_{2}$ were mentioned in (Table 1). The results were shown that nanocoating compound occupied less surface areas with respect of electrospray. The surface coverage area developed by nanocoating and electrospray compound was calculated by formula $\theta=(1-\mathrm{K} / \mathrm{Ko})$. (Figure 10) plotted between $\theta$ (surface coverage area) versus $\mathrm{T}$ (temperature) noticed that temperatures were varies from Nov to Dec but surface coverage area and electrospray values were increased and their values were written in (Table 1).

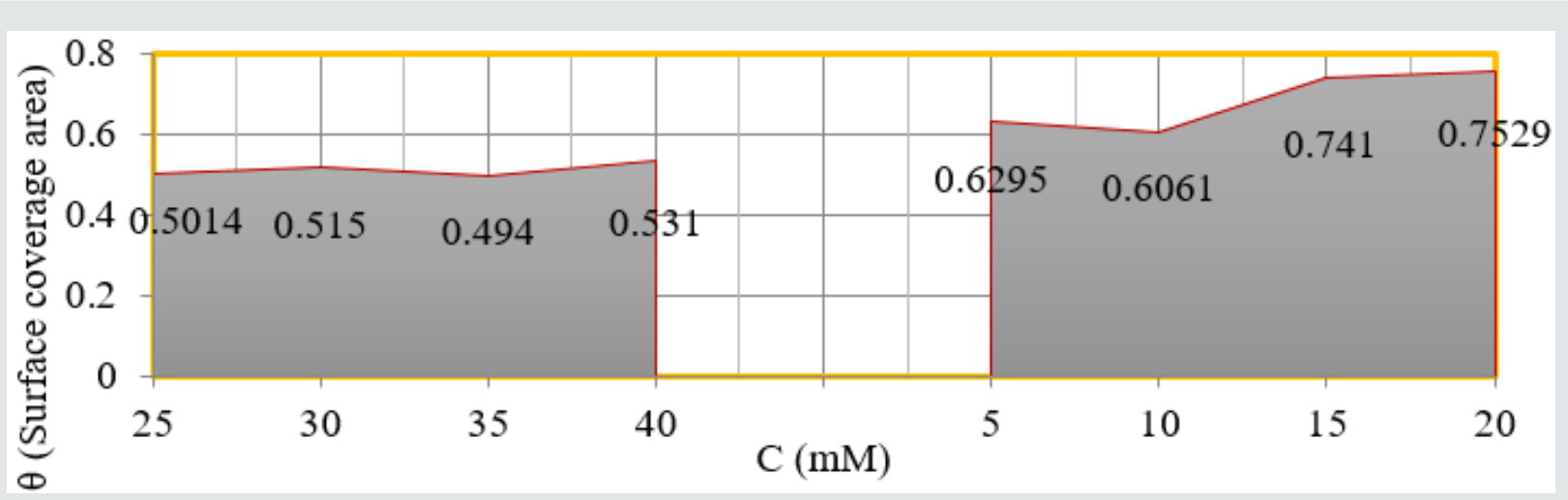

Figure 9: $\mathrm{V}_{\mathrm{s}} \mathrm{C}$ nanocoating and electrospray.

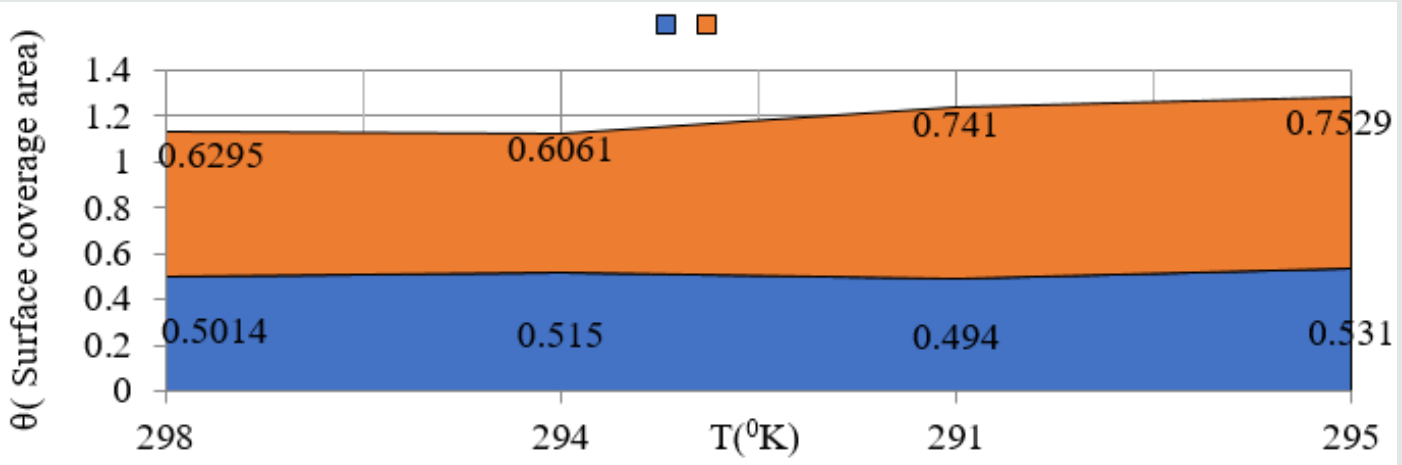

Figure 10: $\theta \mathrm{V}_{\mathrm{s}} \mathrm{T}$ for nanocoating and electrospray.

Table 2: Thermal Parameters of Brass Sculpture in Winter Season by Nanocoating of (6Z)-5,8-dihydrazono-5,8-dibenzo[a,c][8] annulene $[\mathrm{NC}]$ in $\mathrm{SO}_{2}$ Medium.

\begin{tabular}{|c|c|c|c|c|c|c|c|c|c|}
\hline Month & $\mathbf{C}(\mathbf{m M})$ & $\mathbf{T e m p}(\mathbf{K})$ & $\mathbf{S O}_{\mathbf{2}} \mathbf{P P M}$ & $\left.\mathbf{E a}_{\mathbf{o}} \mathbf{( k J / m o l}\right)$ & $\mathbf{E a}(\mathbf{k J} / \mathbf{M o l})$ & $\mathbf{q}(\mathbf{k J} / \mathbf{m o l})$ & $\mathbf{\Delta G}(\mathbf{k J} / \mathbf{M o l})$ & $\mathbf{\Delta H}(\mathbf{k J} / \mathbf{m o l})$ & $\mathbf{\Delta S}(\mathbf{k J} / \mathbf{K})$ \\
\hline Nov & 25 & 298 & 75 & 234 & 222 & -18.06 & -321 & -188 & -151 \\
\hline Dec & 30 & 294 & 90 & 236 & 229 & -33.23 & -328 & -194 & -153 \\
\hline Jan & 40 & 291 & 105 & 246 & 236 & -35.52 & -339 & -199 & -151 \\
\hline Feb & 45 & 295 & 120 & 228 & 221 & -35.23 & -320 & -187 & -150 \\
\hline
\end{tabular}

Composite surface formation was studied by Arrhenius equation, Langmuir isotherm and others thermal parameters like activation energy, heat of adsorption, free energy, enthalpy and entropy and their values were recorded in (Table 2). (Table
2) Thermal Parameters of Brass Sculpture in Winter Season by Nanocoating of (6Z)-5,8-dihydrazono-5,8-dibenzo[a,c][8]annulene [NC] in $\mathrm{SO}_{2}$ Medium. Activation energy of without coating, with coating and electrospray coating were determined by Arrhenius 
equation $\mathrm{d}(\log \mathrm{K}) / \mathrm{dT}=\mathrm{A}-\mathrm{Ea} / 2.303 \mathrm{RT}$ and their values were recorded in (Table 2). The plot between logK versus $1 / \mathrm{T}$ was found to be straight line as shown in (Figure 11). The plot between log $\mathrm{K}$ and $1 / \mathrm{T}$ found to be straight line. It observed that activation before coating activation energy high but decreased after coating. These trends indicated that nanocoating compound adhered on the surface of base metal. Heat of adsorption was calculated by Langmuir isotherm $\log (\theta / 1-\theta)=\log (A C)-q / 2.303 R T$ and their values were mentioned in (Table 2). Its values were found to negative, it indicated nanocoating compound formed chemical bond with base metal. (Figure 12) $\log (\theta / 1-\theta)$ versus $1 /$ T proved results of heat of adsorption.Free energy values of nancoating compound were determined by formula $\Delta G=-2.303 R T \log (33.3 \mathrm{~K})$ and their values were recorded in (Table 2). Their values found to be negative; it noticed that nanocoating compound adhered on the surface of base metal by chemical bond. Enthalpy and entropy values of nanocoating and electrospray compounds were calculated by transition state equation $\mathrm{K}=\mathrm{k} \mathrm{T} / \mathrm{N} \mathrm{h} \mathrm{e}^{\Delta \mathrm{S} / \mathrm{R}} \mathrm{e}^{-\Delta \mathrm{E} / \mathrm{RT}}$ and their values were mentioned in (Table 2). These values were found to be negative which indicated these compounds adhered on the surface of metals. All thermal parameters versus $\mathrm{T}$ (temperature) plotted in (Figure 13) which indicated composite barrier formed on surface of base metal. Thermal parameters Values of $\mathrm{TiO}_{2}$ eleectrospray activation energy, heat of adsorption, free energy, enthalpy and entropy were written in (Table 3 ) and their plot against $\mathrm{T}$ (temperature) in (Figure 14). (Table 3) results indicated electrospray compound formed chemical bond with nanocoating compound. (Table 3) Thermal Parameters of Brass Sculpture in Winter Season by Electrospray of $\mathrm{TiO}_{2}$ in $\mathrm{SO}_{2}$ Medium Potentiostat results were determined with help of equation $\mathrm{I}=\beta \mathrm{a} \beta \mathrm{c} / 2.3(\beta \mathrm{a}+\beta \mathrm{c})$ Ic and corrosion rate $\mathrm{K}=0.128$ $\mathrm{X}$ Ic $\mathrm{X}(\mathrm{E} / \mathrm{d}$ ) ( Ic is corrosion current, equivalent weight and $\mathrm{d}$ is density) and their values were written in (Table 4). (Figure 15) was plotted $\Delta \mathrm{E}$ (corrosion potential versus I(corrosion current density). The results of (Table 4) observed that without coating corrosion potential high but with coating nanocoating and electrospray reduced corrosion potential. (Table 4) Potentiostat results in $\mathrm{SO}_{2}$ in meduim with nanocoating and electrospray.

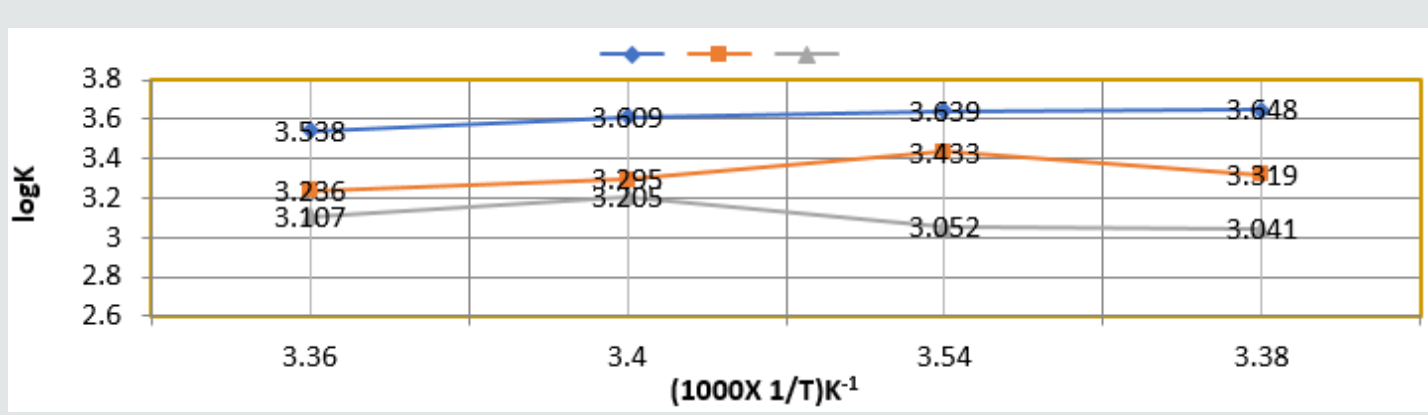

Figure 11: $\log \mathrm{K}_{\mathrm{s}} 1 / \mathrm{T}$ nanocoating and electrospray.

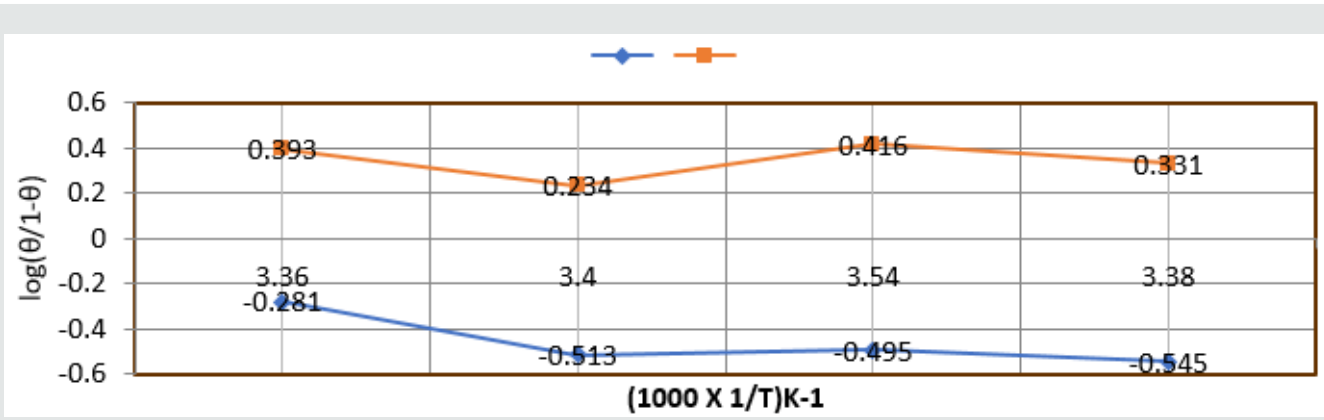

Figure 12: $\log (\theta / 1-\theta) \mathrm{V}_{\mathrm{s}} 1 / \mathrm{T}$ nanocoating and electrospray.

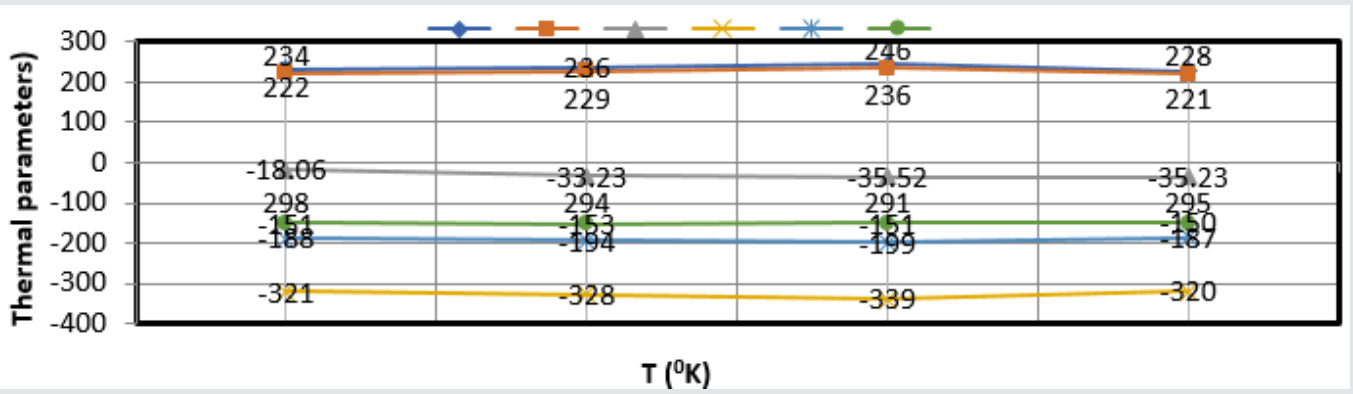

Figure 13: Thermal parameters $\mathrm{V}_{\mathrm{s}} \mathrm{T}$ for nanocoating and electrospray. 


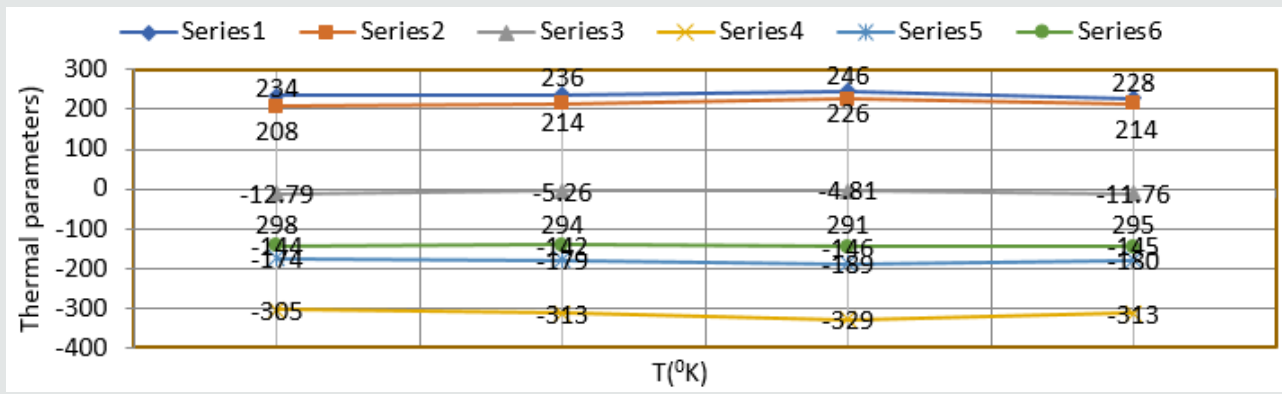

Figure 14: Thermal parameters $\mathrm{V}_{\mathrm{s}} \mathrm{T}$ nanocoating and electrospray.

Table 3: Thermal Parameters of Brass Sculpture in Winter Season by Electrospray of $\mathrm{TiO}_{2}$ in $\mathrm{SO}_{2}$ Medium.

\begin{tabular}{|c|c|c|c|c|c|c|c|c|c|}
\hline Month & $\mathbf{C ( m M )}$ & $\mathbf{T e m p}(\mathbf{K})$ & $\mathbf{S O}_{\mathbf{2}} \mathbf{P P M}$ & $\mathbf{E a}_{\mathbf{o}}$ & $\mathbf{E a}$ & $\mathbf{q}$ & $\mathbf{\Delta G}$ & $\mathbf{\Delta H}$ & $\mathbf{\Delta S}$ \\
\hline Nov & 5 & 298 & 75 & 234 & 208 & -12.79 & -305 & -174 & -144 \\
\hline Dec & 10 & 294 & 90 & 236 & 214 & -05.26 & -313 & -179 & -142 \\
\hline Jan & 15 & 291 & 105 & 246 & 226 & -04.81 & -329 & -189 & -146 \\
\hline Feb & 20 & 295 & 120 & 228 & 214 & -11.76 & -313 & -180 & -145 \\
\hline
\end{tabular}

Table 4: Potentiostat results in $\mathrm{SO}_{2}$ in meduim with nanocoating and electrospray.

\begin{tabular}{|c|c|c|c|c|c|c|c|c|c|c|}
\hline$\Delta \mathbf{E}$ & I & $\beta a$ & Ba & Ic & $\log I c$ & $\mathrm{C}(\mathrm{PPM})$ & Months & $\mathrm{CN}(\mathrm{mM})$ & $\mathrm{CS}(\mathrm{mM})$ & $\mathbf{K}$ \\
\hline 540 & 180 & 230 & 151 & 51 & 1.71 & 75 & Nov & 00 & 00 & 3457 \\
\hline 545 & 195 & 257 & 147 & 67 & 1.82 & 90 & Dec & 00 & 00 & 3578 \\
\hline 559 & 205 & 265 & 187 & 78 & 1.89 & 105 & Jan & 00 & 00 & 3798 \\
\hline 578 & 234 & 278 & 199 & 85 & 1.97 & 120 & Feb & 00 & 00 & 3876 \\
\hline \multicolumn{11}{|c|}{ Potentiostat results in $\mathrm{SO}_{2}$ in medium with nanocoating of $(6 \mathrm{Z})-5,8$-dihydrazono-5,8-dibenzo[a,c] [8]annulene $[\mathrm{NC}]$} \\
\hline 451 & 175 & 180 & 198 & 45 & 1.65 & 75 & Nov & 25 & 00 & 1567 \\
\hline 421 & 163 & 175 & 215 & 57 & 1.75 & 90 & Dec & 30 & 00 & 1610 \\
\hline 396 & 154 & 165 & 231 & 65 & 1.81 & 105 & Jan & 40 & 00 & 1701 \\
\hline 334 & 145 & 154 & 252 & 71 & 1.85 & 120 & $\mathrm{Feb}$ & 45 & 00 & 1802 \\
\hline \multicolumn{11}{|c|}{ Potentiostat results in $\mathrm{SO}_{2}$ in medium with Electrospray of $\mathrm{TiO}_{2}$} \\
\hline 401 & 161 & 147 & 260 & 41 & 1.61 & 75 & Nov & 00 & 5 & 1378 \\
\hline 376 & 144 & 140 & 265 & 49 & 1.69 & 105 & Dec & 00 & 10 & 1402 \\
\hline 347 & 137 & 138 & 271 & 58 & 1.76 & 105 & Jan & 00 & 15 & 1512 \\
\hline 231 & 131 & 128 & 278 & 63 & 1.79 & 120 & Feb & 00 & 20 & 1598 \\
\hline
\end{tabular}

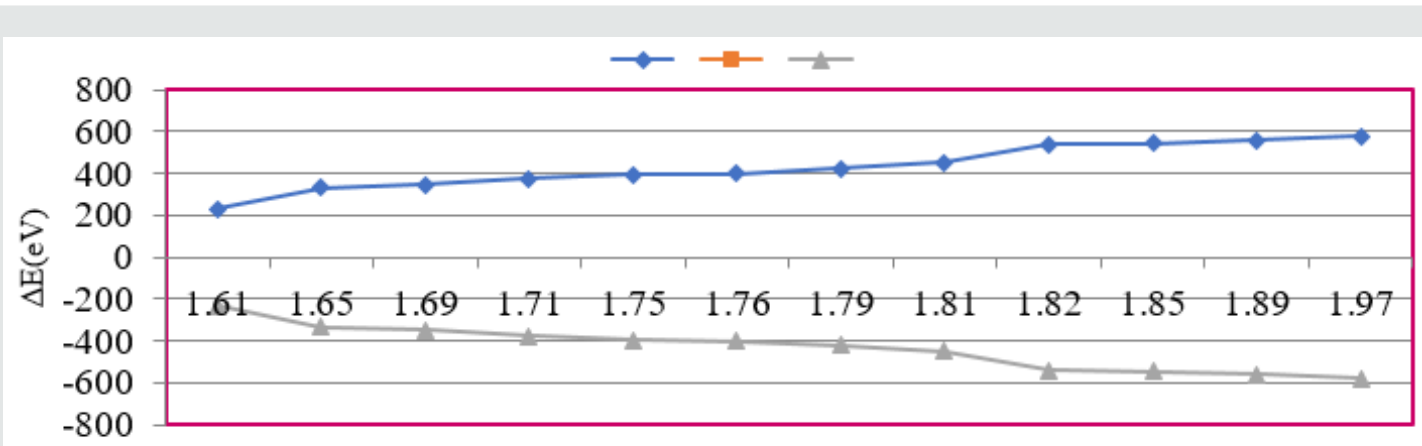

\section{$\mathrm{Ic}(\mathrm{mA}) / \mathrm{cm} 2$}

Figure 15: $\Delta \mathrm{E} \mathrm{V}_{\mathrm{s}} \mathrm{Ic}(\mathrm{mA})$ for nanocoating and electrospray. 


\section{Conclusion}

It observed that winter season $\mathrm{SO}_{2}$ concentration increased. In this season humidity level found to more so it oxidized sulphur dioxide into sulphuric acid and created hostile environment for brass sculpture. It corroded zinc into zinc sulphate in longer period it produced leaching corrosion. Such types of corrosion controlled by the use of nanocoating of (6Z)-5,8-dihydrazono-5,8-dibenzo[a,c] [8]annulene and $\mathrm{TiO}_{2}$ electrospray. The results of activation energy, heat of adsorption, free energy, enthalpy and entropy values indicated that nanocoating compound adhered with chemical bonding. Thermal parameters results of electrospray confirmed that $\mathrm{TiO}_{2}$ bonded with (6Z)-5,8-dihydrazono-5,8-dibenzo[a,c][8] annulene chemical bonding. Both compound created composite barrier on the surface of base metal which produced anticorrosive barrier. The nanocoating compound developed lot of porosities during coating. These porosities blocked by electrospray and it increased coating efficiency and surface coverage area.

\section{Acknowledgement}

Author is thankful to UGC New-Delhi to provide financial grant for this research work. Author is thankful to Professor G Uadhaybhanu, IITD, Dhanbad and Professor Sanjoy Misra, RU, Ranchi for their suggestions and providing laboratory facility.

\section{References}

1. Bhadra S, Singh NK, Khastgir D (2011) Polyaniline based anticorrosive and anti-molding coating. Journal of Chemical Engineering and Materials Science 2(1): 1-11.

2. Bibber JW (2009) Chromium free conversion coating for zinc and its alloys. Journal of Applied Surface Finishing 2(4): 273-275.

3. Szabo T, Molnar Nagy L, Telegdi J (2011) Self-healing microcapsules and slow release microspheres in paints. Progress in Organic Coatings 72: 52-57.

4. Videla H, Herrera LK (2009) Understanding microbial inhibition of corrosion. Electrochem Acta 39: 229-234.

5. Wen NT, Lin CS, Bai CY, Ger MD (2008) Structures and characteristics of $\mathrm{Cr}$ (III) based conversion coatings on electrogalvanized steels. Surf Coat Technol 203: 317.
6. Boerio FJ, Shah P (2005) Adhesion of injection molded PVC to steel substrates. J of Adhesion 81(6): 645-675.

7. Deveci H, Ahmetti G, Ersoz M (2012) Modified styrenes: Corrosion physico-mechanical and thermal properties evaluation. Prog Org Coat 73: 1-7.

8. Genzer J (2005) Templating Surfaces with Gradient Assemblies. J of Adhesion 81: 417-435.

9. Leon Silva U, Nicho ME (2010) Poly(3-octylthiophhene) and polystyrene blends thermally treated as coating for corrosion protection of stainless steel 304. J Solid State Electrochem 14: 1487-1497.

10. Baier RE (2006) Surface behaviour of biomaterials: Surface for biocompatibility. J Mater Sci Mater Med 17: 1057-1062.

11. Rao BVA, Iqbal MY, Sreehar B (2010) Electrochemical and surface analytical studies of the self-assembled monolayer of 5-methoxy2-(octadeclthiol) benzimidazole in corrosion protection of copper, Electrochim. Acta 55: 620-631.

12. Liu XY, Ma HY, Hou MZ (2009) Self-assembled monolayers of stearic imidazoline on copper electrodes detected using electro chemical measurement XPS molecular simulation and FTIR. Chinese Sci Bull 54: 374-381.

13. Liao QQ Yue ZW, Zhou Q (2009) Corrosion inhibition effect of selfassembled monolayers of ammonium pyrrolidine dithiocarbamate on copper. Acta Phys Chin Sin 25: 1655-1661.

14. Zhang DQ, He XM, Kim GS (2009) Arginine self-assembled monolayers against copper corrosion and synergitic effect of iodide ion. J Appl Electrochem 39: 1193-1198.

15. Ghareba GS, Omanovic S (2010) Interaction of 12-aminododecanoic acid with a carbon steel surface: Towards the development of 'green' corrosion inhibitors. Corrosion Sci 52: 2104-2113.

16. Sahoo RR and Biswas SK (2009) Frictional response of fatty acids on steel. J Colloid Interf Sci 333: 707-718.

17. Raman R, Gawalt ES (2007) Selfassembled monolayers of alkanoic acid on the native oxide surface of SS316L by solution deposition. Langmuir 23: 2284-2288.

18. Li DG, Chen SH, Zhao SY (2006) The corrosion Inhibition of the selfassembled $\mathrm{Au}$ and $\mathrm{Ag}$ nanoparticles films on the surface of copper. Colloid Surface 273: 16-23.

19. Cristiani P, Perboni G, Debenedetti A (2008) Effect of chlorination on the corrosion of $\mathrm{Cu}|\mathrm{Ni} 70| 30$ condenser tubing. Electrochim Acta 54: 100107.

20. Cristiani P (2005) Solutions fouling in power station condensers. Appl Therm Eng 25: 2630-2640.

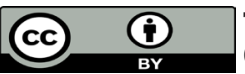

This work is licensed under Creative Commons Attribution 4.0 License

To Submit Your Article Click Here: Submit Article
DOI: 10.32474/MAMS.2019.01.000111

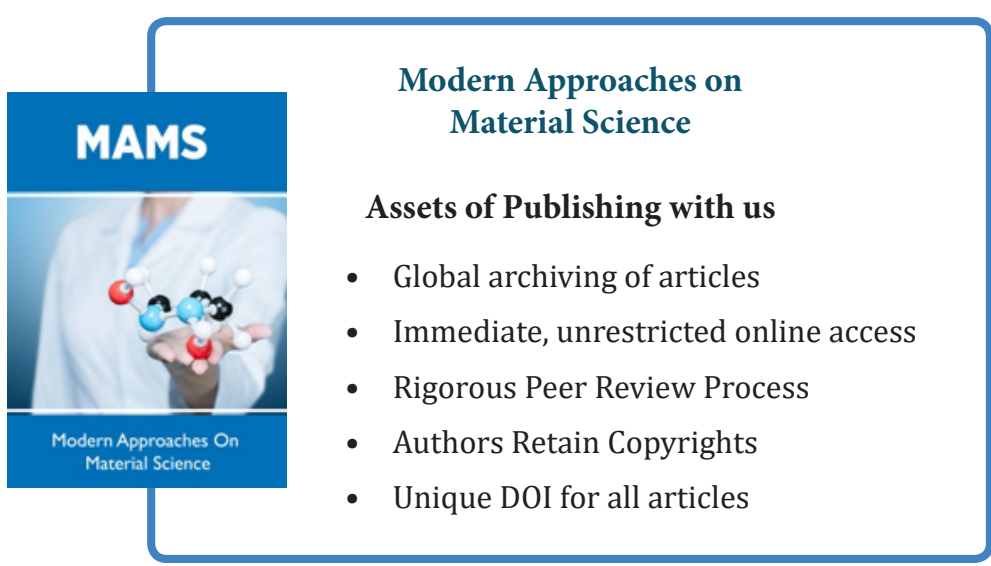

